\title{
Economic Analysis of Profitability in Turf Grasses for Different Methods of Planting
}

\author{
Sithin Mathew ${ }^{1 *}$, G. K. Seetharamu ${ }^{2}$, B. C. Patil ${ }^{1}$, M. Dileepkumar ${ }^{1}$, \\ S. B. Amruta ${ }^{1}$, D. Satish ${ }^{3}$ and S. Mukund ${ }^{1}$ \\ ${ }^{1}$ K. R. C College of Horticulture, Arabhavi- 591218, Karnataka, India \\ ${ }^{2}$ College of Horticulture, Bengaluru- 560065, Karnataka, India \\ ${ }^{3}$ College of Horticulture, Bagakot- 587104, Karnataka, India \\ *Corresponding author
}

A B S T R A C T

Keywords

Mexican grass,

Bermuda grass, B:

$\mathrm{C}$ ratio, Net income

Article Info

Accepted:

18 November 2020

Available Online:

10 December 2020
The profit of turf (lawn) cultivation depends on method of establishment, maintenance and durability of grasses in the field. Among the treatments highest benefit to cost ratio was obtained with chemical weeded plots which were planted with Mexican grass by seed sowing at $5 \mathrm{~g} / \mathrm{m}^{2}(4.16)$ and net income of Rs. 1519759, followed by hand weeded plots which were planted with Mexican grass by seed sowing at $5 \mathrm{~g} / \mathrm{m}^{2}$ (4.03 and net income Rs. 1503759). Whereas, lowest B:C ratio was obtained with hand weeded plots planted with Bermuda grass var. 'Tif dwarf' by seed sowing method at $10 \mathrm{~g} / \mathrm{m}^{2}(2.72)$ and net income of Rs. 1265759.

\section{Introduction}

United States turfgrass industry in 2002 generated total output (revenue) impacts of $\$ 57.9$ billion $(\mathrm{Bn})$, employment impacts of 822,849 jobs, value added impacts of $\$ 35.1$ $\mathrm{Bn}$, labor income of $\$ 23.0 \mathrm{Bn}$, and $\$ 2.4 \mathrm{Bn}$ in indirect business taxes to local and state governments (John et al., 2006). Turf grass industry is often known as "Hidden agriculture industry" because of its immense potential to create income and very less survey has been done on turf grasses (Janakiram et al., 2015). An estimated 32,000 golf courses worldwide (approximately 25,600 $\mathrm{km}^{2}$ ), provide ecosystem goods, services and support as an industry contributing over $\$ 124$ billion globally (Roshini et al., 2017).

Factors which affect the profit of lawn cultivation are its high cost of establishment and maintenance, like cost of mowing, rolling, aeration, de thatching etc. Among them cost of establishment is of prime importance. Weed management in an established lawn is very challenging due to dense cover of grasses and less scope of using 
chemical herbicides. Hence use of preemergent herbicides and soil fumigants are preferred to apply before planting to prevent weed growth.

This experiment was carried out at Department of Floriculture and Landscape Architecture Kittur Rani Channamma College of Horticulture, Arabhavi, UHS, Bagalkot during 2018-2019. The experiment was laid out with three replications with net plot size of $3 \mathrm{~m} \times 3 \mathrm{~m}$ by leaving a spacing of $0.5 \mathrm{~m}$ between plots.

Table 1 reflects the unit cost of all the materials used in the study. Digging (3 times) and double digging (1 time) was done (Total 12 male labors) before planting to bring the soil to fine tilt. Well decomposed Farm Yard Manure was brought from farm office of $\mathrm{KRCCH}$ Arabhavi campus and applied at 5 $\mathrm{kg} / \mathrm{m}^{2}$.

Total $45 \mathrm{~kg}$ of FYM was applied on each plot (1620 kg total), as a basal dose of fertilizer (5 labour 1 day), Chlorpyriphos $(2.5 \mathrm{ml} / \mathrm{L} /$ per meter square) was applied before planting as soil drenching for the control of termites and Phorate granules were broadcasted along the borders of the plot to control white ants entry in to the plots. Pre-emergent herbicide Dizomet $98 \mathrm{MZ}$ (650 Rs. / Kg) was applied on the field at $50 \mathrm{~g} / \mathrm{m}^{2}$ (total $8.1 \mathrm{~kg}$ ) rate $(2$ labors half day).

Among two genotypes studied seeds of Cynodon dactylon (Bermuda grass - 4000 Rs. $/ \mathrm{Kg}$ ) and Zoysia japonica (Mexican grass $3000 \mathrm{Rs} . / \mathrm{Kg}$ ) were collected from a nursery in Hospet taluk of Bellary district in Karnataka. Dibbles of Cynadon dactylon (750 Rs. /Bag) was collected from Pooja nursery in Bengaluru, Karnataka and stolons of Zoysia japonica $\left(80 \mathrm{Rs} . / \mathrm{m}^{2}\right.$ ) was collected from the nursery nearer to K.R.C.C.H, Arabhavi college.
Rooted slips of two turf grass species viz., Cynodon dactylon and Zoysia japonica planted at an escapement of about $10-15 \mathrm{~cm}$ apart on a leveled ground in Zig-Zag rows when the soil was wet after raining or irrigation (3 labors 1 day). It took 40 minutes for completing dibbling in one plot $\left(10 \mathrm{~m}^{2}\right)$ for a single person, likewise for $324 \mathrm{~m}^{2}$ area it took around one full day for three labors. Seeds of both grasses were uniformly broadcasted on the field after mixing with sand at 8:1 ratio followed by sprinkling of soil up to one-centimeter thickness over the seeds (3 labors half day). Mowing (Cutting of grasses) was followed three times for seeded Bermuda grass and Mexican grass (5 labors 2 day) and one time for dibbled grass of both varieties (3 labour 1 day). Irrigation was given at alternate days ( 2 hours for 1 labor for each irrigation).

The benefit to cost ratio was worked out by using the following formula (Kothari et al., 2006)

$$
\text { B:C ratio }=\frac{\text { Gross income (Rs./ha) }}{\text { Cost of cultivation (Rs. /ha) }}
$$

The cost of planting material (Table 2) was highest (Rs. 4,00,000) in Bermuda grass planted by seed sowing at $10 \mathrm{~g} / \mathrm{m}^{2}$ because of high cost of Bermuda grass seeds (Rs. 4000/ $\mathrm{Kg}$ ). The treatment combinations which used Dizomet $98 \mathrm{MZ}$ recorded lowest cost of cultivation (123241 Rs. /ha) due to less labour engagement due to controlled weed population. Cost of cultivation included total labour costs (250 Rs. / day) for, digging, FYM application, Dizomet application, planting, weeding, irrigation, mowing. Mexican grass seeds and dibbles costed less (3000 Rs for seeds and $80 \mathrm{Rs} / \mathrm{m} 2$ for dibbles). By considering less time for planting and low cost of seeds made Mexican grass more profitable compared to all other methods. 
Lawn establishment by dibbling is the costliest method compared to all other methods (Velmurugan et al., 2012). Trenholm (2019) reported that seed sowing is the easiest and most economical way to establish a lawn, but the Success depends on seed quality, proper seeding time, rate and method of seeding.

Table.1 Unit cost of all the materials used in the study

\begin{tabular}{|l|l|c|c|c|c|}
\hline \multirow{2}{*}{ SI. No. } & \multicolumn{1}{|c|}{ Item } & \multicolumn{2}{|c|}{ Mexican grass } & \multicolumn{2}{c|}{ Bermuda grass } \\
\cline { 3 - 6 } & & Seeds (Rs.) & Dibbles (Rs.) & Seeds (Rs.) & Dibbles (Rs.) \\
\hline $\mathbf{1}$ & Plant material $(/ \mathrm{Kg})$ & $3000 / \mathrm{Kg}$ & $80 / \mathrm{m}^{2}$ & $4000 / \mathrm{Kg}$ & $750 / \mathrm{Bag}$ \\
\hline $\mathbf{2}$ & Transportation cost & 1000 & 500 & 1000 & 1200 \\
\hline $\mathbf{3}$ & FYM (/ton) & $1500 / \mathrm{ton}$ & $1500 / \mathrm{ton}$ & $1500 /$ ton & $1500 / \mathrm{ton}$ \\
\hline $\mathbf{4}$ & Plant protection $\left(/ \mathrm{m}^{2}\right)$ & $50 / \mathrm{m}^{2}$ & $50 / \mathrm{m}^{2}$ & $50 / \mathrm{m}^{2}$ & $50 / \mathrm{m}^{2}$ \\
\hline $\mathbf{5}$ & $\begin{array}{l}\text { Chemical weeding (Dizomet) } \\
\text { (/Kg) }\end{array}$ & $650 / \mathrm{Kg}$ & $650 / \mathrm{Kg}$ & $650 / \mathrm{Kg}$ & $650 / \mathrm{Kg}$ \\
\hline $\mathbf{5}$ & Labour cost & $250 /$ labour & $250 /$ labour & $250 /$ labour & $250 /$ labour \\
\hline
\end{tabular}

Table.2 Economics of lawn grasses influenced by weed management methods and method of planting

\begin{tabular}{|c|c|c|c|c|c|c|c|}
\hline Treatments & $\begin{array}{c}\text { Cost of } \\
\text { planting } \\
\text { material } \\
\text { (Rs/ha) }\end{array}$ & $\begin{array}{c}\text { Cost of } \\
\text { herbicide } \\
\text { (Rs/ha) }\end{array}$ & $\begin{array}{c}\text { Cost of } \\
\text { cultivation } \\
\text { (Rs/ha) }\end{array}$ & $\begin{array}{c}\text { Total cost } \\
\text { of } \\
\text { cultivation } \\
\text { (Rs/ha) }\end{array}$ & $\begin{array}{c}\text { Gross } \\
\text { income } \\
\text { (Rs/ha) }\end{array}$ & $\begin{array}{c}\text { Net } \\
\text { income } \\
\text { (Rs/ha) }\end{array}$ & $\begin{array}{c}\text { B:C } \\
\text { Ratio }\end{array}$ \\
\hline $\mathbf{W}_{\mathbf{1}} \mathbf{P}_{\mathbf{1}} \mathbf{T}_{\mathbf{1}}$ & $3,24,000$ & 1,95000 & 123241 & 642241 & $20,00,000$ & 1357759 & 3.11 \\
\hline $\mathbf{W}_{\mathbf{1}} \mathbf{P}_{\mathbf{1}} \mathbf{T}_{\mathbf{2}}$ & $4,00,000$ & 1,95000 & 123241 & 718241 & $20,00,000$ & 1281759 & 2.78 \\
\hline $\mathbf{W}_{\mathbf{1}} \mathbf{P}_{\mathbf{2}} \mathbf{T}_{\mathbf{1}}$ & $1,62,000$ & 1,95000 & 123241 & 480241 & $20,00,000$ & 1519759 & 4.16 \\
\hline $\mathbf{W}_{\mathbf{1}} \mathbf{P}_{\mathbf{2}} \mathbf{T}_{\mathbf{2}}$ & $2,00,000$ & 1,95000 & 123241 & 518241 & $20,00,000$ & 1481759 & 3.85 \\
\hline $\mathbf{W}_{\mathbf{1}} \mathbf{P}_{\mathbf{3}} \mathbf{T}_{\mathbf{1}}$ & $1,80,000$ & 1,95000 & 195616 & 570616 & $20,00,000$ & 1429384 & 3.50 \\
\hline $\mathbf{W}_{\mathbf{1}} \mathbf{P}_{\mathbf{3}} \mathbf{T}_{\mathbf{2}}$ & $1,65,000$ & 1,95000 & 195616 & 555616 & $20,00,000$ & 1444384 & 3.59 \\
\hline $\mathbf{W}_{\mathbf{2}} \mathbf{P}_{\mathbf{1}} \mathbf{T}_{\mathbf{1}}$ & $3,24,000$ & - & 334241 & 658241 & $20,00,000$ & 1341759 & 3.03 \\
\hline $\mathbf{W}_{\mathbf{2}} \mathbf{P}_{\mathbf{1}} \mathbf{T}_{\mathbf{2}}$ & $4,00,000$ & - & 334241 & 734241 & $20,00,000$ & 1265759 & 2.72 \\
\hline $\mathbf{W}_{\mathbf{2}} \mathbf{P}_{\mathbf{2}} \mathbf{T}_{\mathbf{1}}$ & $1,62,000$ & - & 334241 & 496241 & $20,00,000$ & 1503759 & 4.03 \\
\hline $\mathbf{W}_{\mathbf{2}} \mathbf{P}_{\mathbf{2}} \mathbf{T}_{\mathbf{2}}$ & $2,00,000$ & - & 334241 & 534241 & $20,00,000$ & 1465759 & 3.74 \\
\hline $\mathbf{W}_{\mathbf{2}} \mathbf{P}_{\mathbf{3}} \mathbf{T}_{\mathbf{1}}$ & $1,80,000$ & - & 395616 & 575616 & $20,00,000$ & 1424384 & 3.47 \\
\hline $\mathbf{W}_{\mathbf{2}} \mathbf{P}_{\mathbf{3}} \mathbf{T}_{\mathbf{2}}$ & $1,65,000$ & - & 395616 & 560616 & $20,00,000$ & 1439384 & 3.56 \\
\hline
\end{tabular}

*Turf grass selling rate @ Rs. 100 per $\mathrm{m}^{2}$

$\mathrm{W}_{1}$ : Chemical weeding, $\mathrm{W}_{2}$ : Hand weeding, $\mathrm{P}_{1}$ : Seed sowing at $10 \mathrm{~g} / \mathrm{m}^{2}, \mathrm{P}_{2}$ : Seed sowing at $5 \mathrm{~g} / \mathrm{m}^{2}, \mathrm{P}_{3}$ : Stolon dibbling, $\mathrm{T}_{1}:$ Mexican grass, $\mathrm{T}_{2}:$ Bermuda grass

Mexican grass when planted at $5 \mathrm{~g} / \mathrm{m}^{2}$ shown less ground coverage due to poor germination of Mexican grass seeds, whereas, Bermuda grass recorded very good germination hence Bermuda grass can be planted even low seed rates like $3.5 \mathrm{~g} / \mathrm{m}^{2}$ or $2.5 \mathrm{~g} / \mathrm{m}^{2}$. Then Bermuda grass establishment through seed sowing can be the most profitable lawn establishment.
The initial costs of a prairie seeding are often a little higher but significant long-term savings result due to greatly reduced maintenance requirements. Seed cost per acre can vary from $\$ 500$ to $\$ 1500$ per acre. The cost per acre will be reduced significantly for larger projects of 10 acres or more (Neil, D., 2008). 
The ratio of gross income and total cost of cultivation is expressed as Benefit to cost ratio. Grasses are marketed at $100 \mathrm{Rs}$. Per $\mathrm{m}^{2}$ hence for 1-hectare area total gross income of Rs. 20,00,000 is obtained. When gross income is subtracted with total cost of cultivation net income is obtained which is also is an important parameter. Among the treatments highest benefit to cost ratio was obtained with chemical weeded plots which were planted with Mexican grass by seed sowing at $5 \mathrm{~g} / \mathrm{m}^{2}$ (4.16) and net income of Rs. 1519759, followed by hand weeded plots which were planted with Mexican grass by seed sowing at $5 \mathrm{~g} / \mathrm{m}^{2}$ (4.03 and net income Rs. 1503759). Whereas, lowest B:C ratio was obtained with hand weeded plots planted with Bermuda grass var. 'Tif dwarf' by seed sowing method at $10 \mathrm{~g} / \mathrm{m}^{2}$ (2.72) and net income of Rs. 1265759.

\section{References}

John, J. H., Alan, W. H., Charles, R. H., 2006, Economic Impacts of the Turfgrass and Lawncare Industry in the United
States, IFAS extension, university of florida.

Janakiram, T., Ritu, J., Namita, (2015), Introduction to turf grasses. Westville, New Delhi, pp: 12-15.

Roshini, A., Chawla, S. L., Sudha, P., 2017, Evaluation of warm season turf grasses for various qualitative and quantitative traits under Gujarat agro-climatic conditions. Ind. J. Agri. Sci., 87:83-91.

Kothari, S., Kaushick, S. C., Mathur, A. N., 2006, Greenhouse technology for protected cultivation a text book, Khana Publication, Udaipur. 18:115119.

Velmurugan, M., Hemalatha, P., Selvakumar, T., Harisudan, C., 2012, Lawn making : A scientific approach. Rashtriya Krishi, 7: 64-65.

Trenholm, L. E., 2019, Establishing Your Florida Lawn (Revised), IFAS, university of florida.

Neil, D., 2008, Five steps to successful prairie meadow establishment Prairie Nursery.

\section{How to cite this article:}

Sithin Mathew, G. K. Seetharamu, B. C. Patil, M. Dileepkumar, S. B. Amruta, D. Satish and Mukund, S. 2020. Economic Analysis of Profitability in Turf Grasses for Different Methods of Planting. Int.J.Curr.Microbiol.App.Sci. 9(12): 2551-2554.

doi: https://doi.org/10.20546/ijcmas.2020.912.303 